\title{
HTLV-1 bZIP factor enhances TGF-beta signaling through p300 coactivator
}

\author{
Tiejun Zhao', Yorifumi Satou', Kenji Sugata', Patrick L Green², Takeshi Imamura ${ }^{3,4,5}$, Masao Matsuoka ${ }^{\text {* }}$ \\ From 15th International Conference on Human Retroviruses: HTLV and Related Viruses \\ Leuven and Gembloux, Belgium. 5-8 June 2011
}

Adult T-cell leukemia (ATL) is a neoplastic disease caused by Human T-cell leukemia virus type 1 (HTLV1). ATL cells possess a CD4+CD25+ phenotype, similar to that of regulatory $\mathrm{T}$ cells (Treg). The HTLV-1 bZIP factor (HBZ), which is consistently expressed in ATL, has a critical role in the development of ATL and $\mathrm{HAM} / \mathrm{TSP}$. In the present study, we found that HBZ enhanced TGF-beta/Smad transcriptional activity in a manner dependent on p300. Co-immunoprecipitation assay confirmed that HBZ interacted with Smad3, and formed a ternary complex with Smad3 and p300. In the presence of HBZ, the interaction between Smad3 and p300 was enhanced. The N-terminal LXXLL motif of HBZ was essential for HBZ-mediated TGF-beta signaling activation, while Smad3 interacted with HBZ through its $\mathrm{C}$-terminal MH2 domain. Furthermore, physiological level of HBZ could rescue the repressed TGF-beta responses by Tax. We also found that HBZ activated transcription of the Foxp3 gene through its Smad site. Our study shows that HBZ enhances TGF-beta signaling while Tax suppresses this pathway, and this enhancing activity leads to transcription of Foxp3 gene.
doi:10.1186/1742-4690-8-S1-A142

Cite this article as: Zhao et al: HTLV-1 bZIP factor enhances TGF-beta signaling through p300 coactivator. Retrovirology 2011 8(Suppl 1):A142.

\footnotetext{
Author details

${ }^{1}$ Laboratory of Virus Control, Institute for Virus Research, Kyoto University, Kyoto, Japan. ${ }^{2}$ Center for Retrovirus Research and Departments of Veterinary Biosciences and Molecular Virology, Immunology and Medical Genetics, The Ohio State University, Columbus, OH, USA. ${ }^{3}$ Department of Molecular Medicine for Pathogenesis, Ehime University Graduate School of Medicine, Shitsukawa, Toon, Ehime, Japan. ${ }^{4}$ Division of Biochemistry, the Cancer Institute of the Japanese Foundation for Cancer Research (JFCR), Tokyo, Japan. ${ }^{5}$ Core Research for Evolutional Science and Technology (CREST), Japan Science and Technology Agency (JST), Kawaguchi-shi, Saitama, 3320012, Japan.

Published: 6 June 2011

* Correspondence: mmatsuok@virus.kyoto-u.ac.jp

'Laboratory of Virus Control, Institute for Virus Research, Kyoto University, Kyoto, Japan

Full list of author information is available at the end of the article
}

Submit your next manuscript to BioMed Central and take full advantage of:

- Convenient online submission

- Thorough peer review

- No space constraints or color figure charges

- Immediate publication on acceptance

- Inclusion in PubMed, CAS, Scopus and Google Scholar

- Research which is freely available for redistribution
C Biomed Central

(C) 2011 Zhao et al; licensee BioMed Central Ltd. This is an open access article distributed under the terms of the Creative Commons Attribution License (http://creativecommons.org/licenses/by/2.0), which permits unrestricted use, distribution, and reproduction in any medium, provided the original work is properly cited. 